\title{
Long-term data on plankton communities in Torey lakes, a shallow saline lakes, Transbaikalia, Russia
}

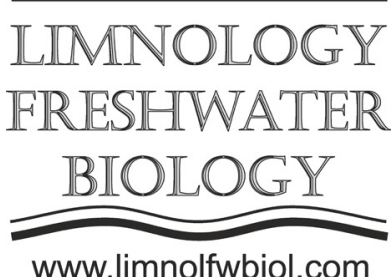

\author{
Afonina E.Yu.*, Tashlykova N.A. \\ Institute of Natural Resources, Ecology and Cryology, Siberian Branch of Russian Academy of Sciences, Nedorezova Str., 16a, Chita, \\ 672039, Russia
}

\begin{abstract}
This study aims to investigate dynamics of environmental and plankton parameters during the drying and initial filling phases of Torey lakes. These lakes located in the South-East Transbaikalia are shallow saline fluctuating lakes. We conducted our studies during different water level phases of the hydrological cycle, including three periods for Zun-Torey Lake: high (1999 and 2003), intermediate (2007, 2011) and low (2014 and 2016) lake levels and two periods for Barun-Torey: high water level (1999 and 2003) and the initial filling phase (2014, 2016, 2018). Fluctuations in water level and environmental conditions (TDS, $\mathrm{pH}$, dissolved oxygen content, water temperature) changes due to dilution and concentration have influence on phyto- and zooplankton structure. Fluctuations of plankton communities are different for each lake and conform the phases of the hydrological cycle. We have identified four stages in changes of plankton community for Zun-Torey Lake as the deeper and slowly drying, and three stages for Barun-Torey Lake as a shallower and rapidly drying.
\end{abstract}

Keywords: phytoplankton, zooplankton, species diversity, density, water level, Torey lakes

The southeast Transbaikal region, with its arid and extremely continental climate, is characterized by morphodynamic variability (Bazhenova, 2013). The interdecadal cycles, which last 27-35 years, are controlled by the variations in atmospheric moistening, with relatively moist and very cold periods alternating with dry and relatively warm periods (Obyazov, 2012). Long-term cyclic changes have been observed in the levels of the largest saline Torey lakes (Barun-Torey (the surface area is $550 \mathrm{~km}^{2}$ and the average depth is $2.5 \mathrm{~m})$ and Zun-Torey $\left(285 \mathrm{~km}^{2}\right.$ and the average depth is $4.5 \mathrm{~m}$ )). We conducted our studies during different water level phases of the hydrological cycle, including three periods for Zun-Torey Lake: high (1999 and 2003), intermediate $(2007,2011)$ and low (2014 and 2016) lake levels and two periods for Barun-Torey: high water level (1999 and 2003) and the initial filling phase (2014, 2016, 2018). This study aims to investigate the scarcely known dynamics of environmental and plankton parameters during the drying and initial filling phases of lakes (Fig.).

Two rivers (Uldza and Imalka) flow into the Barun-Torey Lake. The outflow only occurs in high water years, while in dry years, the riverbeds dry up. Because of this and a decrease in precipitation, the lake quickly becomes shallow, and its surface area shrinks, sometimes resulting in the drying-up of the lake. When the water level decreases, the shallow Barun-Torey
Lake dries up sooner. Barun-Torey Lake completely dried out in 2010, and Zun-Torey Lake in 2017. Since 2014 at the northernmost point of Lake Barun-Torey, small water bodies (pools) have been observed on its bottom; they are sustained by rainfall, and permafrost and groundwater discharge through the fracture at the western shore of the lake. Currently (according to 2019 data) the dried bottom of Lake Barun-Torey is a steppe with small lakes (pools) in the northern end of the lake. Zun-Torey Lake is viscous impassable salt marshes with water from atmospheric precipitation.

In Zun-Torey Lake, the salinity, $\mathrm{pH}$, dissolved oxygen content and temperature increased from 2.1 to $18.5 \mathrm{~g} / \mathrm{L}$, from 9 to 9.9 , from 5.6 to $8.4 \mathrm{~g} / \mathrm{L}$, and from 21.7 to $25.5^{\circ} \mathrm{C}$ respectively, and transparency decreased from 0.5 to $0.2 \mathrm{~m}$ during transition from high to low water levels (Afonina and Tashlykova, 2019). In BarunTorey Lake, TDS $=2.1 \mathrm{~g} / \mathrm{L}, \mathrm{pH}=9, \mathrm{~T}=21.3{ }^{\circ} \mathrm{C}$ during high water level period. The filling temporary pools on the Barun Torey dry bed were oligohaline (TDS $=0.7-$ $1.0 \mathrm{~g} / \mathrm{l})$, alkaline $(\mathrm{pH}=8.2-9)$, well warmed up (25.9$30.2^{\circ} \mathrm{C}$ ), and with transparency $0.1-0.3 \mathrm{~m}$.

Fluctuations in water level and hydrochemical compound changes due to dilution and concentration had influence on plankton community structure. In Zun-Torey Lake, total species number of phytoplankton changed from 11 (intermediate lake level) to 20 (low water level). The total abundance and biomass of algae 


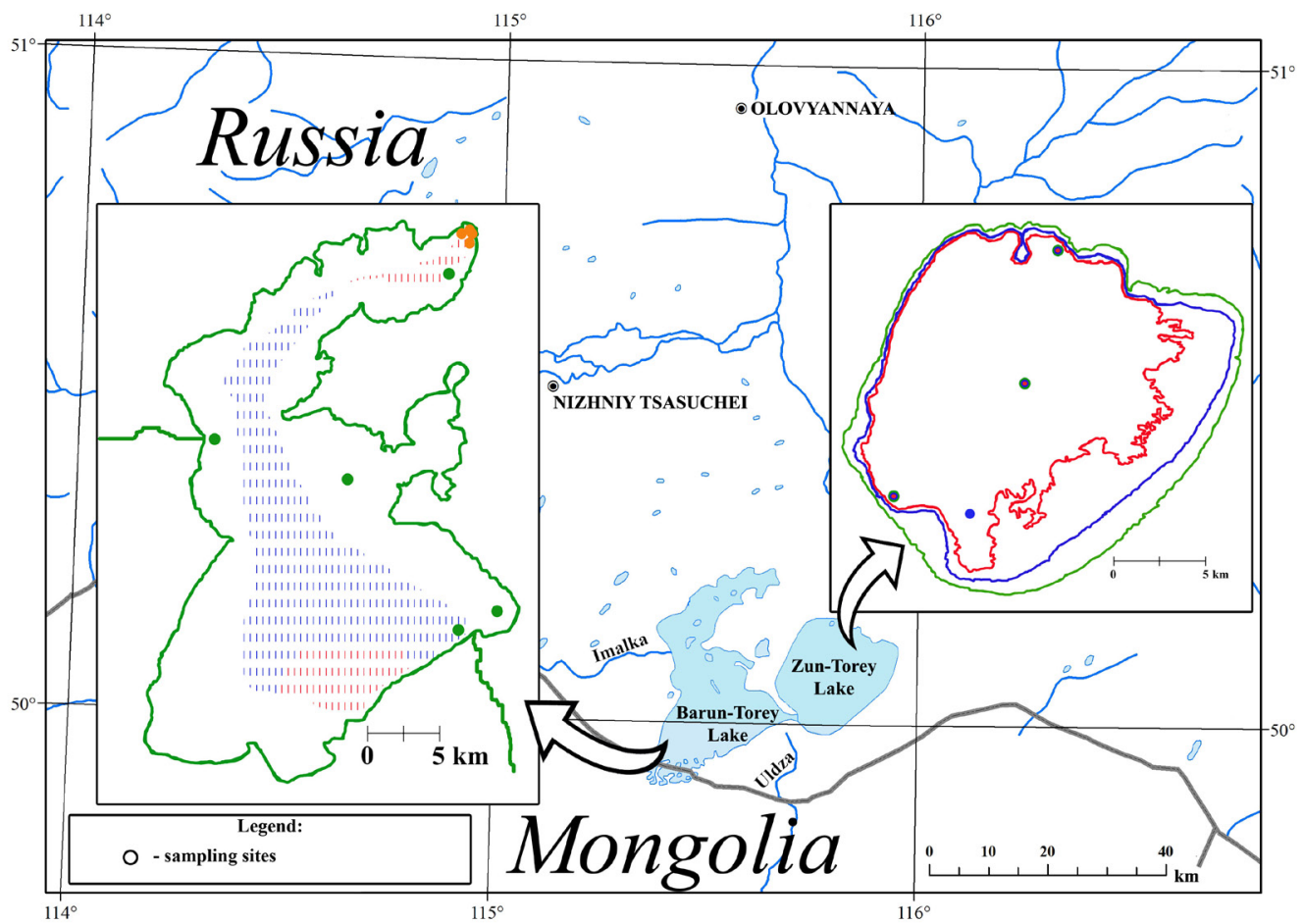

Fig. Geographic location of the Torey lakes (Transbaikalia, Russia) and its changing surface area during different water level periods. Dots indicate sampling sites. Green is high water level, blue - intermediate water level, red - low water level, orange initial filling phase.

decreased from $95.9 \pm 21.8 \times 10^{3}$ cells/L and $60.5 \pm 35.9$ $\mathrm{mg} / \mathrm{m}^{3}$ to $38.3 \pm 8.6 \times 10^{3}$ cells $/ \mathrm{L}$ and $7.8 \pm 5.1 \mathrm{mg} / \mathrm{m}^{3}$ respectively during transitions from high to low water levels. Interannual succession of the phytoplankton dominant species was in the direction of: diatoms (Rhopalodia gibba) and greens (Schroederia setigera) $\rightarrow$ greens (S. setigera, Lemmermannia komarekii) $\rightarrow$ greens (Oocystis borgei, L. komarekii) and cyanobacteria (Gloecapsa sp.). A decrease in zooplankton species diversity (from 16 to 4 species) and an increase in the abundance (from $68.6 \pm 13$ to $530.5 \pm 227.2 \times 10^{3}$ ind./ $\mathrm{m}^{3}$ ) and biomass (from $1.8 \pm 0.5$ to $24.5 \pm 14.3 \mathrm{~g} / \mathrm{m}^{3}$ ) were noted with the water level decreased. In high water years, Filinia longiseta, Diaphanasoma mongolianum, Arctodiaptomus bacillifer dominated, in intermediate and low ones Moina brachiata, Metadiaptomus asiaticus were.

In Barun-Torey Lake, phytoplankton consisted of 24 species, and density amounted to $944.5 \pm 390.7$ $\times 10^{3}$ cells $/ \mathrm{L}$ and $1298.7 \pm 799.8 \mathrm{mg} / \mathrm{m}^{3}$ during high lake level. Green algae (O. borgei, $O$. submarina) dominated. Zooplankton consisted of 20 species, and abundance and biomass averaged 140.2 $\pm 34.2 \times 10^{3}$ ind. $/ \mathrm{m}^{3}$ and $4.4 \pm 1.4 \mathrm{~g} / \mathrm{m}^{3}$. Species $F$. longiseta, $M$. brachiata, Arctodiaptomus niethammeri, Cyclops strenuus were dominants.

In filling pools, phytoplankton contained 7-25 species. Abundance and biomass varied widely and averaged $22.6-1260 \times 10^{3}$ cells/L and $19.1-1271 \mathrm{mg} /$ $\mathrm{m}^{3}$. The dominant complex differed and consisted of S. setigera, Tetraëdron incus from greens, Navicula sp. from diatoms and Coelomoron pusillum, Oscillatoria sp., Gloecapsa sp., from cyanobacteria. Zooplankton included 39 species. The total abundance $(140.2 \pm 34$. 2 $1267.7 \pm 664.6 \times 10^{3}$ ind. $\left./ \mathrm{m}^{3}\right)$ and biomass $(4.4 \pm 1.4$
$117.9 \pm 62 \mathrm{~g} / \mathrm{m}^{3}$ ) varied widely. Dominant composition was different; wherein Thermocyclops dybowski prevailed in all pools.

Fluctuations of plankton communities were different for each lakes and conformed the phases of the hydrological cycle. We documented some stages of plankton community changes (in species diversity and density) with changing environmental conditions. There were four stages for Zun-Torey Lake (1-high water level - a high species diversity of planktonic algae and invertebrates species, the values of the phytoplankton abundance and biomass were maximal, zooplankton were minimal; 2-intermediate level - decreases in the species diversity of algae and invertebrates, decreases in the algae density and increases in the zooplankton abundance; 3-low level - increases in the species number of algae due to increase benthic form and decreases in the total abundance of algae, further decrease in the species richness of zooplankton, and an increase in the abundance and biomass due to increase of some species; 4-drying out - aquatic biota was absent). There were three stages for Barun-Torey Lake (1-high water level - plankton community develop was the same as for Zun-Torey Lake; 2-drying out planktonic flora and fauna was not found; 3-initial filling phase - multiple increase in the diversity and density of hydrobionts).

\section{Acknowledgements}

We would like to thank all colleagues who helped to collect the samples. This study was supported by the Program for Basic Research of the Siberian Branch of the Russian Academy of Sciences, project no. IX.137.1.1. 


\section{References}

Afonina E.Yu., Tashlykova N.A. 2019. Plankton of saline lakes in Southeastern Transbaikalia: transformation and environmental factors. Contemparary Problems of Ecology 12(2): 155-170. DOI: 10.1134/S1995425519020021

Bazhenova O.I. 2013. Modern dynamics of lake-fluvial systems of Onon-Torey High Plain (Southern Transbaikalia). Vestnik Tomskogo Gosudarstvennogo Universiteta [Tomsk State University Bulletin] 371: 171-177. (in Russian)

Obyazov V.A. 2012. Change of climate and hydrological regime of the rivers and lakes in Dahurian ecoregion. In: Kirilyuk O. (Ed.), Problemy adaptatsii $\mathrm{k}$ izmeneniyu klimata $\mathrm{v}$ basseynakh rek Daurii: ekologicheskiye i vodokhozyaystvennyye aspekty [Problems of adaptation and climate change in the river basins of Dahuria: ecological and hydroeconomic aspects]. Chita, pp. 24-45. (in Russian) 